\title{
MULTISCALE ENVIRONMENTAL MONITORING IN URBAN TOPOCLIMATE
}

\author{
ROCHA, Angela Fátima da - angela.rocha@cba.ifmt.edu.br \\ Instituto Federal de Mato Grosso / IFMT
}
SILVA, Ernany Paranaguá da - ernany03@gmail.com Instituto Federal de Mato Grosso / IFMT

MUSSIS, Carlo Ralph de - carlo@fisica.ufmt.br Universidade Federal de Mato Grosso / UFMT

GOMES, Raphael de Souza Rosa - raphael@ic.ufmt.br Universidade Federal de Mato Grosso / UFMT

\author{
NEVES, Geraldo Aparecido Rodrigues - garneves@gmail.com \\ Universidade Federal de Mato Grosso / UFMT \\ NOGUEIRA, Marta Cristina Albuquerque - mcjanp@gmail.com \\ Universidade Federal de Mato Grosso / UFMT
}

\begin{abstract}
Climate is a complex system subject to much natural and anthropogenic interference. Urban microclimates and topoclimates need effective methodologies to localize coexisting phenomena, including multiscale approaches that demonstrate their relational character. Air temperature, air relative humidity, and wind are microclimatic variables that can be evaluated with respect to their qualitative energy flow characteristics. The technical performance of this monitoring depends on a good estimate of the statistics of the digital signal assessed, which in turn represents greater care in the management and implementation of structural change indicators derived from frequencydomain modeling. Therefore, this study aimed to analyze the power spectra of the air temperature, air relative humidity and wind data series using the traditional Morlet Continuous Wavelet Transform (CWT) and the Cross Wavelet Transform (XWT), with Wavelet Coherence (WC) analysis. The daily, monthly and annual scales were studied, and the results demonstrated significant interrelationships between the variables. The WC values found were validated by the Monte Carlo method, scalograms and spectrograms, representing seasonal and daily cycle frequencies. The urban fractions presented behavior in accordance with the seasonality of tropical climates of the Cerrado, as well as of interference of the urban roughness. The CWT, XWT and WC tools are adequate for urban monitoring and planning analyses, qualitatively reflecting the urban dynamics of microenvironments.
\end{abstract}

Keywords: Urban Monitoring; micrometeorological variables; Wavelets; Cross Wavelet Transformed; Environmental Sustainability

\section{MONITORAMENTO AMBIENTAL MULTIESCALA EM TOPOCLIMA URBANO}

RESUMO: O clima é um exemplo de um sistema que pode ser caracterizado como complexo, sujeito às interferências humanas e de diversas variáveis naturais. Os microclimas e topoclimas urbanos necessitam de metodologias eficazes na localização de fenômenos coexistentes com abordagens multiescala que demonstrem seu caráter relacional. A temperatura do ar, a umidade relativa do ar e o vento são variáveis microclimáticas que podem ser avaliadas quanto a suas características qualitativas dos fluxos de energia. O desempenho técnico desse monitoramento depende de uma boa estimativa da estatística do sinal digital estudado, o que representa, por sua vez, maior cuidado na gestão e implementação de indicadores de mudanças estruturais derivados de 
modelagem no domínio da frequência. Portanto, o objetivo deste trabalho foi analisar os espectros de potência das séries de dados de temperatura do ar, umidade relativa do ar e vento por meio das ferramentas Transformada Wavelet de Morlet Tradicional, Transformada Wavelet Cruzada, com análise de Coerência Wavelet. As escalas diárias, mensais e anuais foram estudadas e os resultados demonstraram as inter-relações significantes entre as variáveis. As coerências wavelets encontradas foram validadas pelo Método de Monte Carlo escalogramas e espectrogramas representando frequências sazonais e de ciclo diário. As frações urbanas apresentaram comportamento em conformidade com a sazonalidade dos climas tropicais de cerrado, bem como, das interferências da rugosidade urbana. As ferramentas Transformadas Wavelet Contínua TWC, Transformada Wavelet Cruzada TWX e Coerência Wavelet CW mostraram ser adequadas em análises de monitoramento e de planejamento urbanos, refletindo qualitativamente a dinâmica urbana dos microambientes.

Palavras chaves: Monitoramento Urbano; Variáveis Micrometeorológicas; Ondaletas; Transformada Wavelet Cruzada; Sustentabilidade Ambiental

\section{MONITOREO AMBIENTAL MULTIESCALA EN TOPOCLIMA URBANO}

RESUMEN: El clima es un ejemplo de un sistema que puede ser caracterizado como complejo, sujeto a las interferencias humanas y de diversas variables naturales. Los microclimas y topoclimas urbanos necesitan metodologías eficaces en la localización de fenómenos coexistentes con enfoques multiescala que demuestren su carácter relacional. La temperatura del aire, la humedad relativa del aire y el viento son variables microclimáticas que pueden ser evaluadas en cuanto a sus características cualitativas de los flujos de energía. El desempeño técnico de este monitoreo depende de una buena estimación de la estadística de la señal digital estudiada, lo que representa, a su vez, mayor cuidado en la gestión e implementación de indicadores de cambios estructurales derivados de modelado en el ámbito de la frecuencia. Por lo tanto, el objetivo de este trabajo fue analizar los espectros de potencia de las series de datos de temperatura del aire, humedad relativa del aire y el viento por medio de las herramientas Transformada Wavelet de Morlet Tradicional, Transformada Wavelet Cruzada, con análisis de Coherencia Wavelet. Las escalas diarias, mensuales y anuales fueron estudiadas y los resultados demostraron las interrelaciones significativas entre las variables. Las coherencias wavelets encontradas fueron validadas por el método de Monte Carlo, escalogramas y espectrogramas que representaban frecuencias estacionales y de ciclo diario. Las fracciones urbanas presentaron comportamiento de acuerdo con la estacionalidad de los climas tropicales de cerrado, así como de las interferencias de la rugosidad urbana. Las herramientas Transformadas Wavelet Continua TWC, Transformada Wavelet Cruzada TWX y Coherencia Wavelet CW mostraron ser adecuadas en análisis de monitoreo y de planificación urbanos, reflejando cualitativamente la dinámica urbana de los microambientes.

Palabras Clave: Monitoreo Urbano; Variables Micrometeorológicas; ondas; Transformada Wavelet Cruzada; Sostenibilidad del medio ambiente

\section{INTRODUCTION}

Climate is a system that may be characterized as complex, as it is subject to anthropogenic and natural variability. Working with climate and weather phenomena means thinking in terms of possibilities rather than of absolute certainties. Urban monitoring alone is a fertile field for scientific discussion and opens new paths into decision-making processes.

Air temperature, relative humidity, and wind are commonly used as variables or parameters in climate and weather analyses, and are valuable for any study or model as they play major roles in the different natural and physical processes. Urban and rural microclimates should be increasingly explored in search of effective methodologies to identify coexisting phenomena at various time scales. The case of Brazil is not different, particularly the Central-West 
region. The climatic environment analyses of a given location can be evaluated according to the periodicity and behavior of its most common variables, such as air temperature, relative humidity, and wind. A detailed study of its energy levels in time scales, the case of wavelet mathematical tools - particularly the cross wavelet (XWT) and wavelet coherence (WTC) transforms, enable a scientific approach that can hardly be adopted by means of other methods. These transforms work in two ways: as a core where analyses can be integrated to extract information on processes and/or as a basis for representing or characterizing processes (VILANI et al., 2018) (TORRENCE \& COMPO, 1998), (ARAGHI, 2015), (FENG \& LIANG, 2016).

Today, the history of urban climate and planning, as well as urban restructuring and legislation, have important links to the vegetation of microclimates (OKE, 2006), (ROMERO, 2012), as urban climate is a result of the interactions among urban factors, regional climate, the pre-existing physical environment, and soil use and occupation (SHINZATO \& DUARTE, 2018), (VAL, 2016), which should be guided by microclimatic analysis and models of urban systems (SHINZATO \& DUARTE, 2018), (VILANI et al., 2018), (VAL, 2016). The low- and high-frequency time patterns related to the natural dynamics of these environments are complex and require variables capable of representing them. They should also be modeled before and after the physical process of the environments, or often in correlation with urban changes (De Paulo et al., (2015), (Oliveira, 2006), (ABARBANEL et al., 1993), (NICOLIS \& PRIGOGINE, 1989). Other factors involved are thermal comfort, air quality, and a myriad of anthropogenic actions that have been studied by several researchers (KATZSCHNER, 1997), (ALCOFORADO, 1999), (ANDRADE, 2005), (COX, 2008), (GOMES \& LAMBERTS, 2009), (MATZARAKIS et al., 1999), (ROMERO, 2013), (SCHMITZ, 2014), (NUNES, 2016), (PROJETO BIOMA, 2017).

The environmental and economic value of an urban fraction may be different from that of a forest fraction, but anthropogenic action concerning changes in soil use is crucial to understand and determine the interaction between climate and the vulnerability of this biome.

Studies on temperature, relative humidity, and wind favor the understanding of the urban microclimate and its interaction with the topoclimate and even mesoclimate scales. Therefore, this study aimed to analyze the air temperature, air relative humidity, and wind data series in the frequency domain by means of mathematical tools, characterizing the wavelets from the spectral viewpoint using the traditional Continuous Wavelet Transform (CWT) and analyzing the statistical coherence of the models obtained by means of the Cross Wavelet Transform (XWT), making use of the Wavelet Coherence (WC).

\section{MATERIALS AND METHODS}

The city of Cuiabá, capital of the state of Mato Grosso, Brazil, is located at $15^{\circ} 35^{\prime} \mathrm{S}$ and $56^{\circ} 06^{\prime} \mathrm{W}, 165 \mathrm{~m}$ a.s.l. The region encompassing the city is referred to as the "depression of Cuiaba". The municipality has an area of $3,224.68 \mathrm{~km}^{2}$, of which $254.57 \mathrm{~km}^{2}$ is occupied by its urban fraction and $2,970.11 \mathrm{~km}^{2}$ by the rural fraction. It is located at the intersection of three major Brazilian ecosystems: the Cerrado at its surroundings; the Pantanal to the South; and the Amazon forest to the North. Predominant vegetation is Cerrado, with the densest vegetation found around water courses (CUIABÁ, 2017).

According to the Köppen's climate classification, climate in the region is Aw -tropical with dry winter. The mean annual precipitation is $1387.8 \mathrm{~mm}$, 
concentrated between November and March (89.9\%), with a dry season between June and August (4.0\%) (SETTE, 2000; SAMPAIO, 2006; VIDAL, 2012; BARROS, 2018).

The average annual temperature varies between 25 and $26{ }^{\circ} \mathrm{C}$, whereas the maximum temperatures often exceed $35^{\circ} \mathrm{C}$, nearly all year round (ALVARES et al., 2013), (LABAKI, 2013). The average annual maximum temperature in Cuiabá ranges from 31 to $34^{\circ} \mathrm{C}$, with peaks above $35^{\circ} \mathrm{C}$ between September and October. In contrast, the average annual minimum temperature ranges from 18 to $21{ }^{\circ} \mathrm{C}$, with an average of eight cold periods a year, resulting from the presence of Atlantic polar masses, which usually bring rain (BARROS, 2018). The average annual relative humidity is $70 \%$, but it drops during the winter, reaching levels around $12 \%$ at the peak of the dry season (NOGUEIRA et al., 2012).

According to Sampaio (2006) and Vidal (2012), the average annual cumulative rainfall is $1500 \mathrm{~mm} /$ year. Predominant wind direction is $\mathrm{N}$ (North) and NW (Northwest) during most of the year, and S (South) during the winter. Cuiabá is located at a geographical depression, which causes extremely low frequency and average speed of wind and reduces convective heat transfer, which further underscores the influence of the built fraction on temperature (SAMPAIO, 2015). The highest temperatures occur in August, September and October, whereas the lowest temperatures are observed in May, June and July.

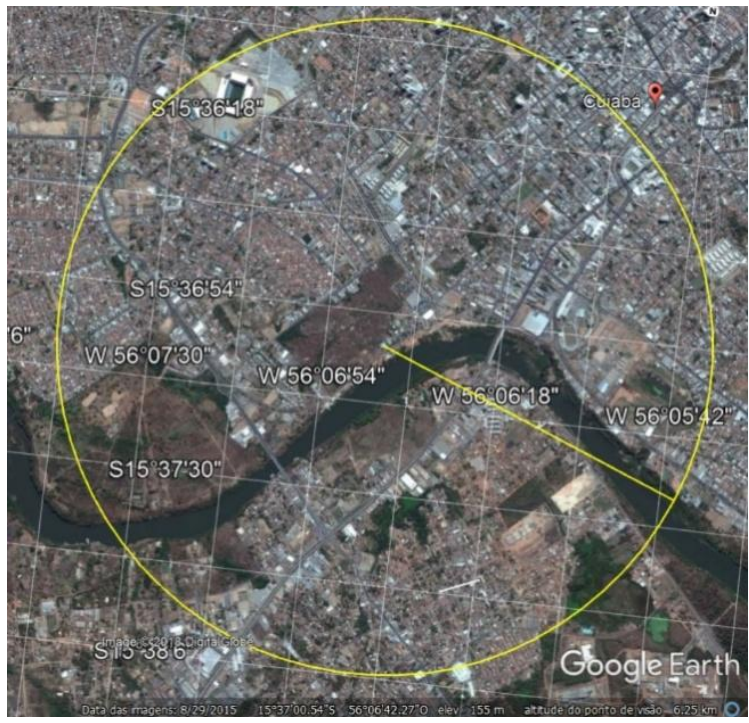

Figure 1 - Topoclimate (radius of 2000 m); dry season 2015

Source: Google Earth Pro.

Urban areas are considered to be open systems with transfers of energy, matter, and amount of movement with the surroundings. As such, they are nonlinear dynamic systems. The study area was selected for its diverse soil coverage (KATZSCHNER, 1997). The variables were studied as time series so as not to modify their originality. The temperature, relative humidity, and wind data were collected at 5-min intervals and analyzed during the dry and rainy seasons for specific time periods between 2015 and 2016. ONSET ${ }^{\circledR}$ micro- $^{-}$ weather stations with storage sensors and remote data transmission were used in this study (ROCHA, SILVA, MUSSIS, 2018). 
The temperature, relative humidity, and wind data were pre-processed, and the graphs of the traditional Continuous Wavelet Transforms (CWT) used were analyzed. The data normality tests were carried out according to Addison (2017). All statistical tests were performed considering a significance level of $5 \%$. As the Morlet wavelet was used in an undulating manner, the temperature, relative air humidity, and wind variables were evaluated for adherence to normal distribution by the Kolmogorov-Smirnov test.

By means of the algorithms studied, the data time series were decomposed into frequency components in which the spectra found translated the key characteristics of the series collected. According to Torrence and Compo (1999), Morlet's studies gave rise to the first generative base function (prototype functions), called "mother wavelets", indicated in the literature as $(\psi(\mathrm{t}))$ and named Morlet Wavelet. They are processes of scaling by means of a parameter $a$, dilating or compressing $(\psi(\mathrm{t})) \rightarrow(\psi(2 \mathrm{t})$, and a parameter $b$, moving $(\psi(\mathrm{t})) \rightarrow(\psi(\mathrm{t}+1))$, thus forming small analytical wavelets. In a complex physical environment, it is important to investigate the relations between the different physical phenomena that occur in the natural system. This study used the algorithms proposed by C. Torrence, available at http://paos.colorado.edu/research/wavelets, accessed on: October 27, 2016; and by Grinsted, J. C., available at http://noc.ac.uk/using-science/crosswaveletwavelet-coherence, accessed on: October 27, 2016.

The complex Morlet wavelet was used and defined by a periodical function combined to a Gaussian curve. It refers to the Fourier transform of the Morlet wavelet, which has the shape of a Gaussian curve displaced along the central frequency axis of the Gaussian spectrum. Addison (2017) explained that the displaced Gaussian curve is the reversed imaginary part when the complex conjugate is used in the transformation, which leads to a quarter-cycle lag of the real part of the signal. Therefore, the Fourier Transform of the Morlet Wavelet was chosen as the characteristic frequency of the Morlet Wavelet. Thus, by means of Equation $1, \psi$ is the wavelet value; $w_{0}$, the number of oscillations within the wavelet; and $t$, the analysis period or time scale.

$$
\psi(t)=\pi^{-0,25} e^{-i w_{0} t} e^{-1 / 2 t^{2}}, w_{0} \geq 5 \quad \text { Equation } 1
$$

The Wavelet Transform and the Morlet Wavelet are efficient in handling microclimatic variables; the first, for being able to decompose another function into different frequency and time scales, and the latter, for presenting low oscillation in the extraction of characteristics. Wavelets have moving windows in time and space that expand or compress to capture low and high frequency signals, assisting with the analysis of the microclimatic variables adopted (EHLERS, 2009). This fact enables the faithful monitoring of these frequencies at the end of the process, as well as the subsequent generation of a methodology to monitor urban areas. According to Addison (2017), the value of $w_{0}$ was set to 6 with a view to meeting the condition of admissibility. This means that, for this value, errors due to a mean not equal to zero are fewer than the typical rounding errors (DOMINGUES et al., 2016), (FRICKS, 1998). The Cross Wavelet Transform (XWT) spectrum was used to examine the relationship and similarity between two signals by means of Equation 2. 


$$
X W_{f, g}(a, b)=W_{f}(a, b) W_{g}(a, b) \quad \text { Equation } 2
$$

The methodology is presented as a function $f(t)$ developed by the decomposition into a base composed of Wavelet functions $\psi(\mathrm{t})$. The mother wavelet, with its transforms $W x(\mathrm{~s}, \mathrm{t})$ and $W y(\mathrm{~s}, \mathrm{t})$ and their conjugates, generated the two air temperature $(X(t))$ and relative humidity $(Y(t))$ series and their respective transforms $W x(\mathrm{~s}, \mathrm{t})$ and $W y(\mathrm{~s}, \mathrm{t})$, where $s$ is the scale, and $t$ is the time (TORRENCE and WEBSTER, 1999). Equation 2 expresses this product of the Wavelet Transform coefficients in a given scale " $a$ " in the surroundings $(t=b)$, where the energy spectra are crossed and the XWT spectrum coefficients reveal the existence of a high correlation between functions $f(t)$ and $g(t)$. This process highlights the energy regions that coincide between the signals within the transform range and determines the relative phase between the digital signals. Interpreting the phase location arises as a measure of the difference between the two signals analyzed in time (b) and scale (a), as the phase captures the coordination between the components in the time-frequency space. The XWT power is the background spectrum energy, where the $95 \%$ confidence level was used.

The Wavelet Coherence (WC) constitutes the XWT normalized spectrum, the XWT spectrum coefficients show the existence of a high degree of correlation between $f(t)$ and $g(t)$. Equation 3 presents the factor used to normalize the energy density and the smoothing operator of the time and scale used.

$$
W C_{f, g}(a, b)=\frac{\mid s\left(\left.s^{-1} x w_{f, g}(a, b)\right|^{2}\right.}{s\left(s^{-1}\left|w_{f}(a, b)\right|^{2}\right) s\left(s^{-1}\left|w_{g}(a, b)\right|^{2}\right)} \quad \text { Equation } 3
$$

Monte Carlo tests were carried out by the algorithm in the verification of the $95 \%$ significance level for white Gaussian noise filters. The edge effects were considered according to the cone of influence (COI) inserted in the CWT, XWT, and WC scalograms. Therefore, the variables were analyzed and their characteristics, trends, seasonal variations, and dominant periodicities were studied according to the frequency and/or period variable and the space and/or position variable by means of the CWT, XWT and WC. According to Domingues et al. (2016), there are many classical "cross-correlation" methods to determine the coherent structures between two signals.

\section{RESULTS AND DISCUSSION}

From April 23, 2015 to September 22, 2015, the dry season, the highest monthly temperature and relative humidity averages occurred in September (30.7 $\left.{ }^{\circ} \mathrm{C} \pm 3.7\right)$ and April $(82.0 \% \pm 6.9)$, respectively; the lowest monthly averages occurred in July $\left(25.5{ }^{\circ} \mathrm{C} \pm 3.3\right)$ and August $(47.6 \% \pm 8.2)$, with a thermal amplitude of $5.2{ }^{\circ} \mathrm{C}$ for temperature and $34.4 \%$ for humidity. As for the fall, the maximum and minimum daily temperatures, i.e., the hottest and coldest days, were $29.3^{\circ} \mathrm{C} \pm 3.3$ and $18.0{ }^{\circ} \mathrm{C} \pm 1.0$; the relative humidity values in the most humid and the driest days were of $95.1 \% \pm 7.9$ and $63.7 \% \pm 14.8$, respectively. In the winter, the temperatures of the hottest and coldest days were of $34.4^{\circ} \mathrm{C} \pm 4.1$ and $17.1^{\circ} \mathrm{C} \pm 1.1$, and the most humid and driest days 
presented relative humidity values of $90.4 \% \pm 7.6$ and $31.0 \% \pm 9.7$, respectively.

From September 23, 2015 to March 21, 2016, the rainy season, the highest monthly average temperature and relative humidity occurred in October $\left(29.8{ }^{\circ} \mathrm{C} \pm 3.8\right)$ and January $(83.0 \% \pm 7.6)$. The lowest monthly average temperature occurred in January $\left(27.5{ }^{\circ} \mathrm{C} \pm 1.6\right)$ and October $(64.4 \% \pm 12.8)$, with a thermal amplitude of $2.3^{\circ} \mathrm{C}$ for temperature and $18.6 \%$ for humidity. As for the spring, the maximum and minimum daily temperatures, i.e., the hottest and coldest days presented temperatures of $34.9{ }^{\circ} \mathrm{C} \pm 4.1$ and $19.8{ }^{\circ} \mathrm{C} \pm 1.6$, whereas the relative humidity values on the most humid and driest days were $88.2 \% \pm 2.7$ and $42.0 \% \pm 12.1$, respectively. In the summer, the hottest and coldest days had temperatures of $31.6^{\circ} \mathrm{C} \pm 3.7$ and $25.0^{\circ} \mathrm{C} \pm 1.5$, and the most humid and driest days presented relative humidity values of $93.2 \% \pm 6.5$ and $63.3 \% \pm 14.5$, respectively.

From March 22, 2015 to September 21, 2016, the dry season during the fall and winter, the highest monthly average temperature and relative humidity occurred in April $\left(28.0{ }^{\circ} \mathrm{C} \pm 4.3\right)$ and May $(79.7 \% \pm 8.0)$, respectively. The lowest monthly averages occurred in June $\left(23.4{ }^{\circ} \mathrm{C} \pm 3.5\right)$ and July $(57.0 \%$ \pm 9.4 ), with a thermal amplitude of $4.6{ }^{\circ} \mathrm{C}$ for temperature and $22.7 \%$ for humidity. As for the fall, the maximum and minimum daily temperatures, i.e., the hottest and coldest days, were $31.7 .3{ }^{\circ} \mathrm{C} \pm 3.7$ and $15.4{ }^{\circ} \mathrm{C} \pm 0.4$; the relative humidity values on the most humid and the driest days were $92.7 \%$ \pm 4.9 and $59.5 \% \pm 13.1$, respectively. In the Winter, the hottest and coldest days had temperatures of $32.4^{\circ} \mathrm{C} \pm 4.8$ and $13.5{ }^{\circ} \mathrm{C} \pm 0.7$, and the relative humidity values on the most humid and driest days were $94.6 \% \pm 3.9$ and $38.9 \% \pm 16.2$, respectively. The data series of the temperature, relative humidity, and wind are shown in Figure 2. 
Air Temperature and Air Relative Humidity

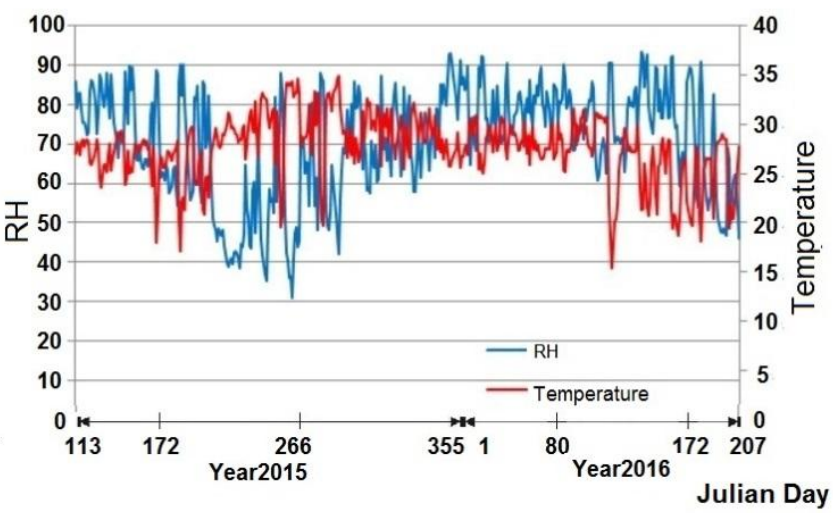

Air Temperature and Wind
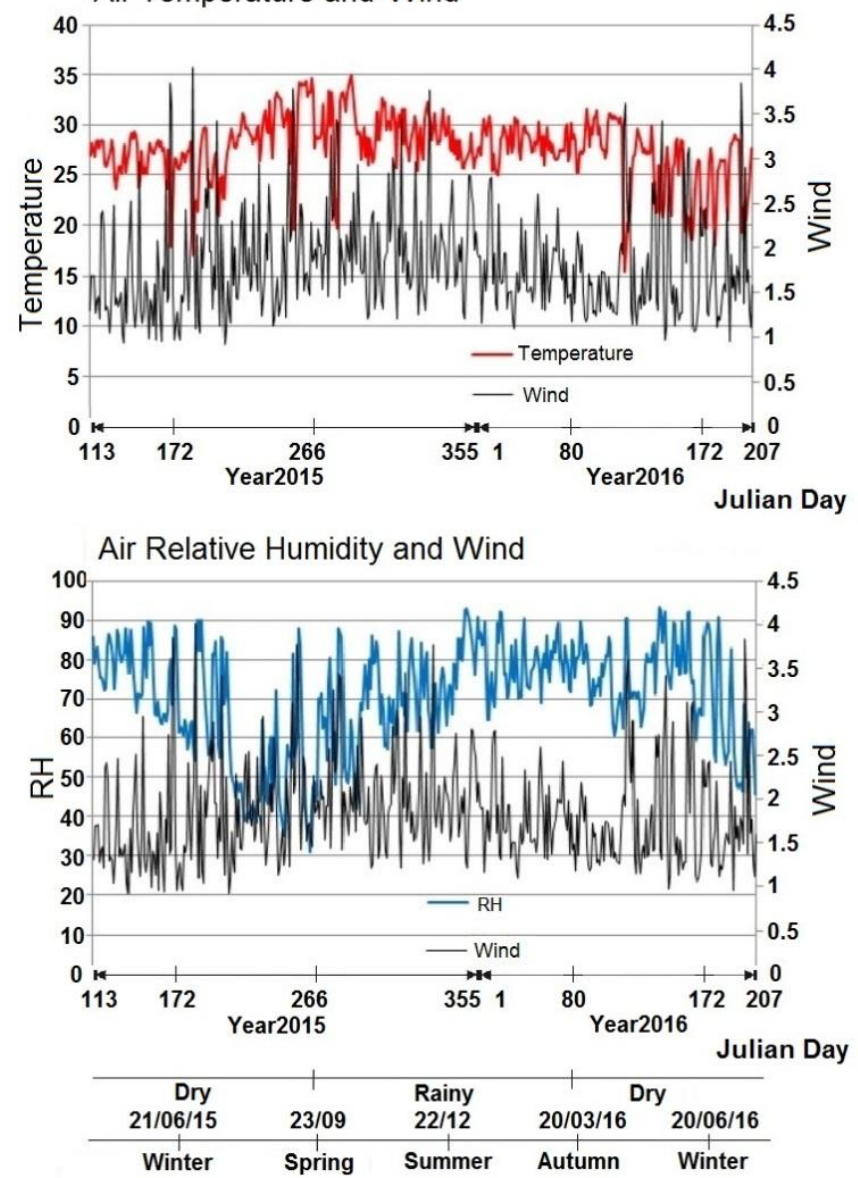

Figure 2 - Data series of the temperature, relative humidity and wind variables; daily averages

The Fall-Winter is characterized by a hot and dry climate with daily averages of temperature and relative humidity of $27.6^{\circ} \mathrm{C} \pm 3.1^{\circ} \mathrm{C}$ and $65.2 \%$ $\pm 16.3 \%$ for the dry period, respectively. On the other hand, the Spring-Summer continues to be a hot season, although more humid. For the rainy season, the daily averages of temperature and relative humidity were $28.9^{\circ} \mathrm{C} \pm 2.3^{\circ} \mathrm{C}$ and $73.6 \% \pm 10.9 \%$, respectively-this behavior is typical of Cerrado regions. 
As this is one of the hottest capital cities of Brazil, the influence of the built portion on the temperature is noteworthy, as well as the consequences of the hot weather to urban areas of Cerrado. It is also pointed out that, although the daily averages do not constitute extreme values, during the dry seasons and at the hottest hours of the day, the maximum temperature reached $41.5{ }^{\circ} \mathrm{C} \pm 0.6$ ${ }^{\circ} \mathrm{C}$ along with a minimum relative humidity of $18.6 \% \pm 0.5 \%$. The Cerrado climate of the Brazilian Central-West region is also characterized by low temperatures on some days, whether or not they co-occur with low relative humidity-in practice, these days constitute the winter in Cuiabá. In view of these extreme and uncomfortable conditions, studies for monitoring microclimatic spaces and the topoclimate by means of spectral analyses and micrometeorological variables are justified.
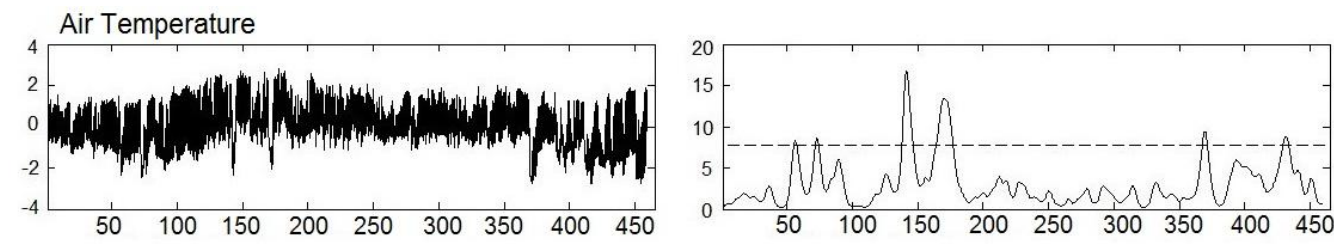

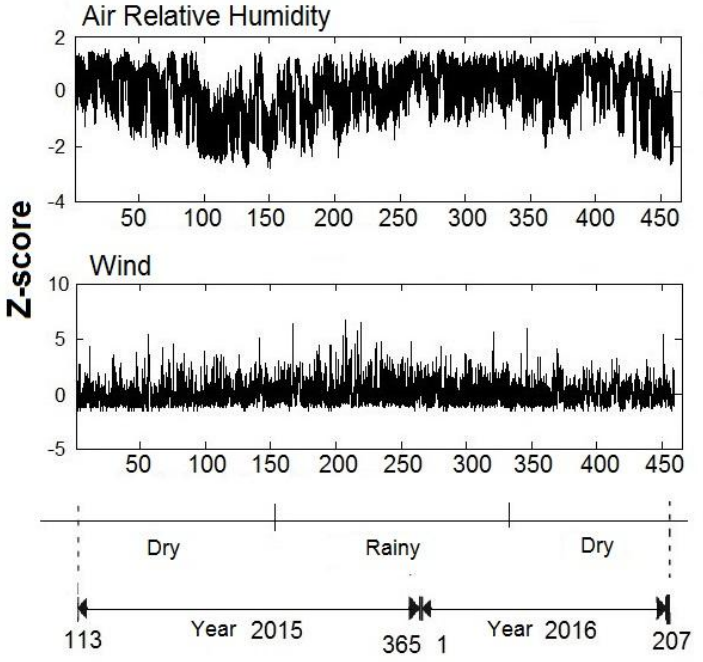

(a)
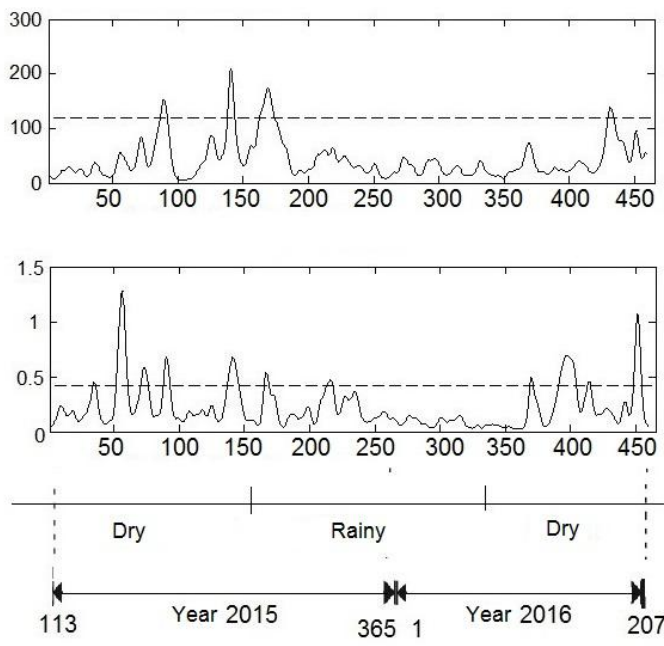

(b)

Time (days)

Figure 3 - (a) Z-scores of the temperature, relative humidity and wind data series, and (b) annual mobile variances $(\sigma 2)$ of variables

In the urban fraction analyzed, the variability of temperature, relative humidity, and wind (as shown in Figure 3) presents random fluctuations typical of red noise (with a higher number of values with low frequencies) occurring more often during the dry season and in the intermediary dry/humid period. In these times of the year, the temperatures are usually high during the day and may fall rapidly with the arrival of Atlantic air masses, constituting temperature inversion phenomena. The urban seasonal frequencies of the Cerrado in the dry and rainy seasons are shown in Figure 3.

The elementary properties of the Morlet Wavelet, linearity and energy conservation, covariance, and localization in space and scale were used under conditions of admissibility, similarity, invertibility, and regularity (Addison, 
2017). The traditional Continuous Wavelet Transform (CWT) results in colored scale diagrams for average annual energy, which allow seasonal analyses. The urban seasonal frequencies of the Cerrado in the dry and rainy seasons are shown by means of the Global Wavelet Spectra in Figure 4. The scalograms are formed by coefficients that represent the signal variation intensity and phase; the modules of these coefficients show the signal amplitude, and the energy supplied is equal to its density. The color palette used has a logarithmic distribution and the significance of the amplitude of the coefficients found using the CWT verified: the spectrum edges, where the so-called cone of influence (COI) defines the decay of the spectrum on each scale, and the significance level of $95 \%$ for the background red noise in areas circled in black in the time domain.

The CWT for the temperature, relative humidity (Figure 4), and wind (Figure 5) variables show periodicities of $24 \mathrm{~h}$ according to the rotation movement of the planet, with slight peaks at the high frequency for the air temperature and relative humidity series in their global spectrograms (EPG), represented in the red and orange in the scales, and with the highest peak for the variable wind.
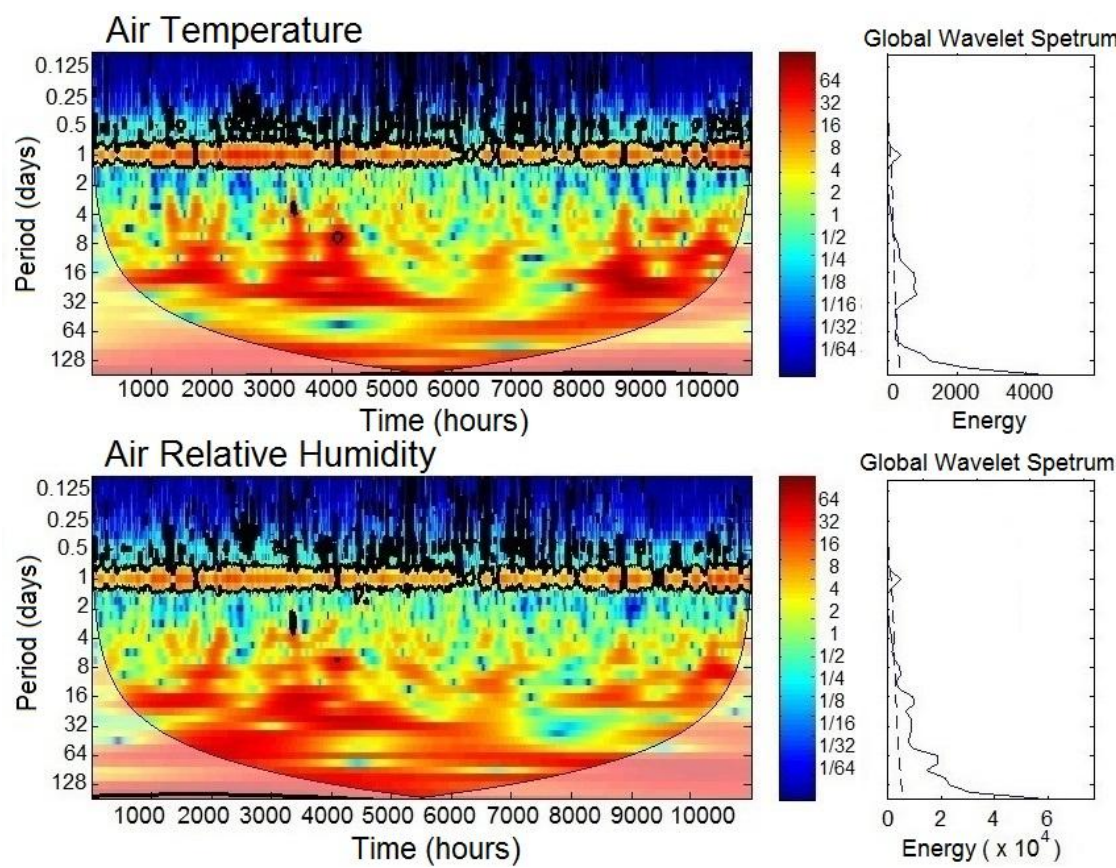

Figure 4 - Annual traditional CWT of air temperature and relative humidity

In the rainy season, from approximately $5000 \mathrm{~h}$ into the time domain, there were practically no coincident periodicities in the CWT of the variables. Thus, the discrepancy between temperature and relative humidity is noteworthy, showing the invertibility between these variables. Increases in red noise were identified in the data series, having occurred in the same time domains identified in the CWT scalograms. Since the wavelet transform was the basis, these scalograms showed the high frequencies located in time, and the adjustment was finer, more sensitive and short in duration, which allowed visualization of the signal analyzed at a more detailed scale with better time resolution, especially in the case of abrupt changes. In low frequencies, the 
wavelet basis framed the signal at a larger, less detailed and softer scale, allowing visualization of the global characteristics - a resolution with a frequency finer than the temporal, which makes localization in frequency easier.

Figure 5 shows the CWT for the wind variable throughout the entire dry season of the 2015 series. The periodicity of the daily cycle was not effectively uniform across the time domain studied. There was a high frequency peak in the EPG power spectrum. This peak suggests an increase in the amount of energy, possibly generated by an increase in the convection winds (BIUDES et al., 2009). The periodicities of temperature and relative humidity related to the dry season were also confirmed, as well as their respective fortnightly periodicity, with high recurrence, which restates a dominant periodicity. In this context, values below 4 days, for instance, were not interpreted as recurrences.
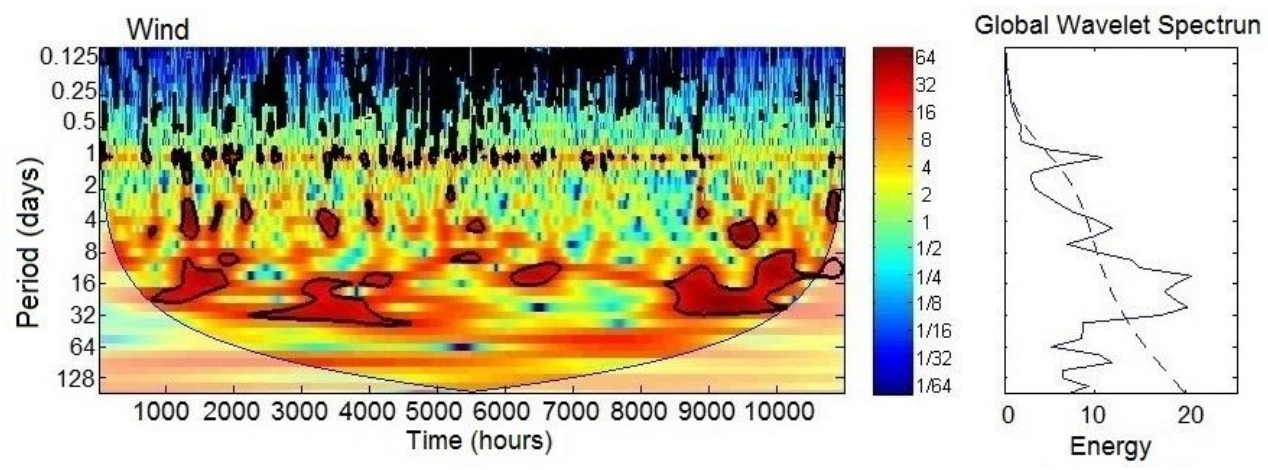

Figure 5 - CWT of the wind data series

Areas detected by the interrelations between the variables are found in the XWT (Figures 6, 7, and 8), where the phase is the measure of the difference between the signals analyzed, which allows the scalograms of the cross spectrum generated by the algorithms, indicating results verified as true in the interrelation significance test between two time series, enabling analysis of the results and of the CWT, XWT and WC. Subsequently, the WC was applied to test the significance of the interrelations found by means of the XWT. 


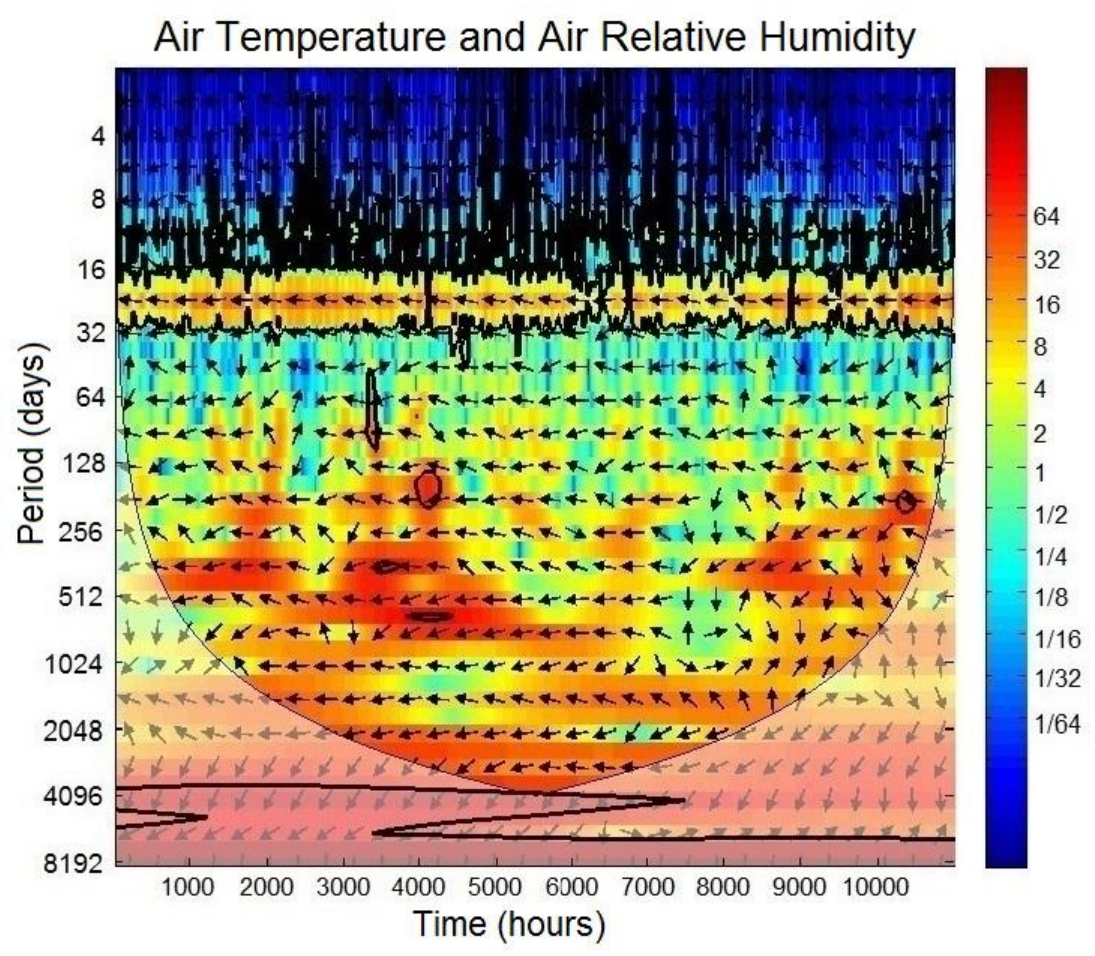

Figure 6 - XWT of air temperature and relative humidity

The XWT of the air temperature, air relative humidity, and wind data series (Figures 6, 7 and 8 , respectively) confirm the periodicities of $24 \mathrm{~h}$ over the period studied. Figure 6 shows the variables in anti-phase, as the arrows point from right to left. Figures 7 and 8 show the variables moving towards the phase or away from it, as the arrows are found in intermediate positions. If they were in phase, the arrows would point from left to right. 


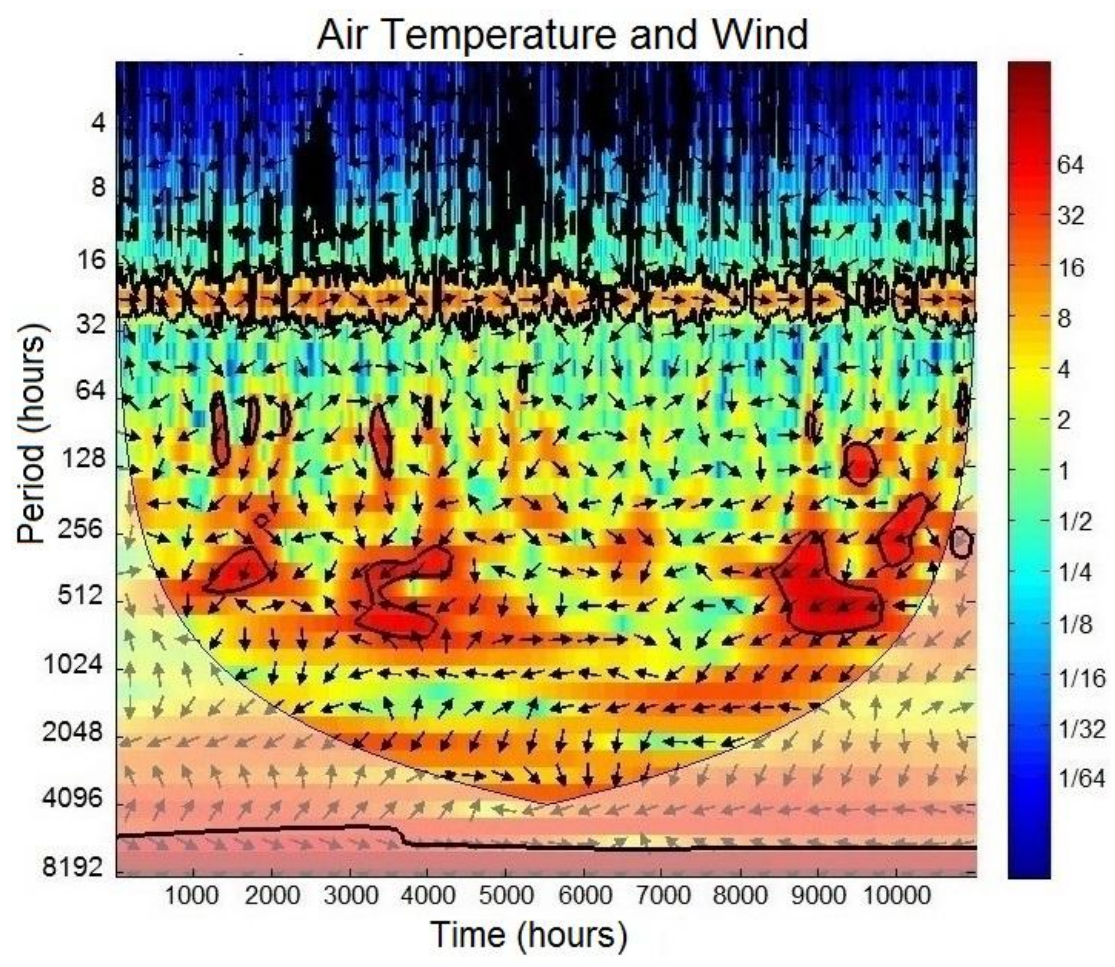

Figure 7 - XWT of air temperature and wind

In the XWT of Figures 6,7 and 8 , the fortnightly periodicities with significance of $95 \%$ are circled in black. All the areas in red indicate high significance levels, although below $95 \%$, such as in Figure 6 . The other red areas in Figures 7 and 8 effectively represent levels of significance starting from $95 \%$. Thus, the interrelations are a measure of association between the two temperatures and relative humidity data series, which allow visualization of coinciding events on the scales and frequencies at each moment in time of the signals of the respective series - the recurrences. 


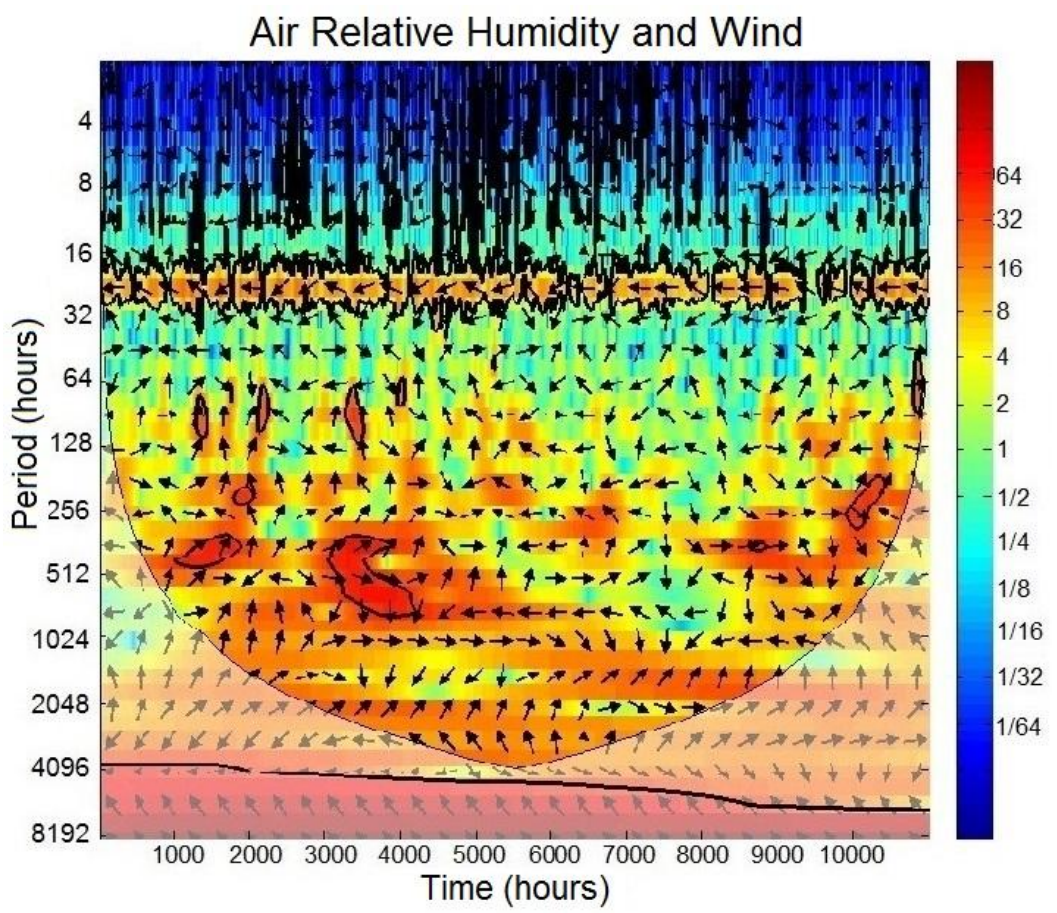

Figure 8 - XWT of relative humidity and wind

In the algorithms, the coefficients in the Wavelet Coherence (WC) are signals acting on the time axis or time domain, and when the Fourier transform occurs and the time domain turns into spectral or frequency domain, if the wavelet and the signal analyzed are positive, the contribution to the wavelet equation will also be positive. If both contributions are negative, the contribution will still be positive. If the signal and the wavelet have opposite signs, the contribution will be negative. In short, signals are framed into the phase or antiphase. The WC coefficients are also shown in color map-like scalograms (Figures 9,10 , and 11) for the original signals. The horizontal axis represents the time domain and the vertical axis shows the scales used to calculate the WC. Figures 9, 10 and 11 show the WC with the interrelations of the time series after the Monte Carlo tests. 


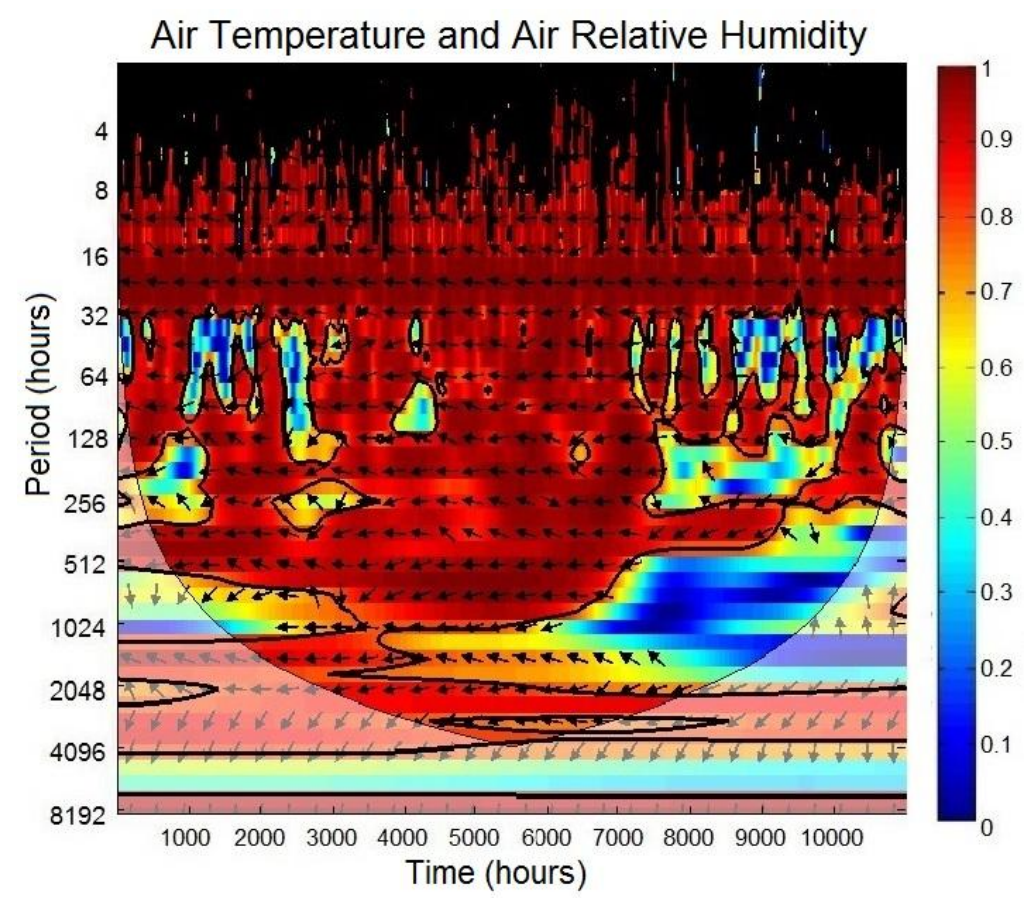

Figure 9 - WC of temperature and relative humidity

The WC of the temperature and relative humidity (Figure 9), temperature and wind (Figure 10), and relative humidity and wind (Figure 11) qualitatively show the dark red color in the scalograms, representing the verification of the interrelations captured by the XWT between temperature and relative humidity (Figure 9), for instance. This is marked not only for the $24 \mathrm{~h}$-cycle, but also for the entire background spectrum of the XWT (Figure 6) in its fortnightly periodicities, representing the anti-phase behavior among the variables (arrows pointing from right to th left). In Figure 9, the areas circled in black correspond to frequencies that have been evaluated as highly significant (recurrence higher $>95 \%$ ) according to the Monte Carlo simulation. 


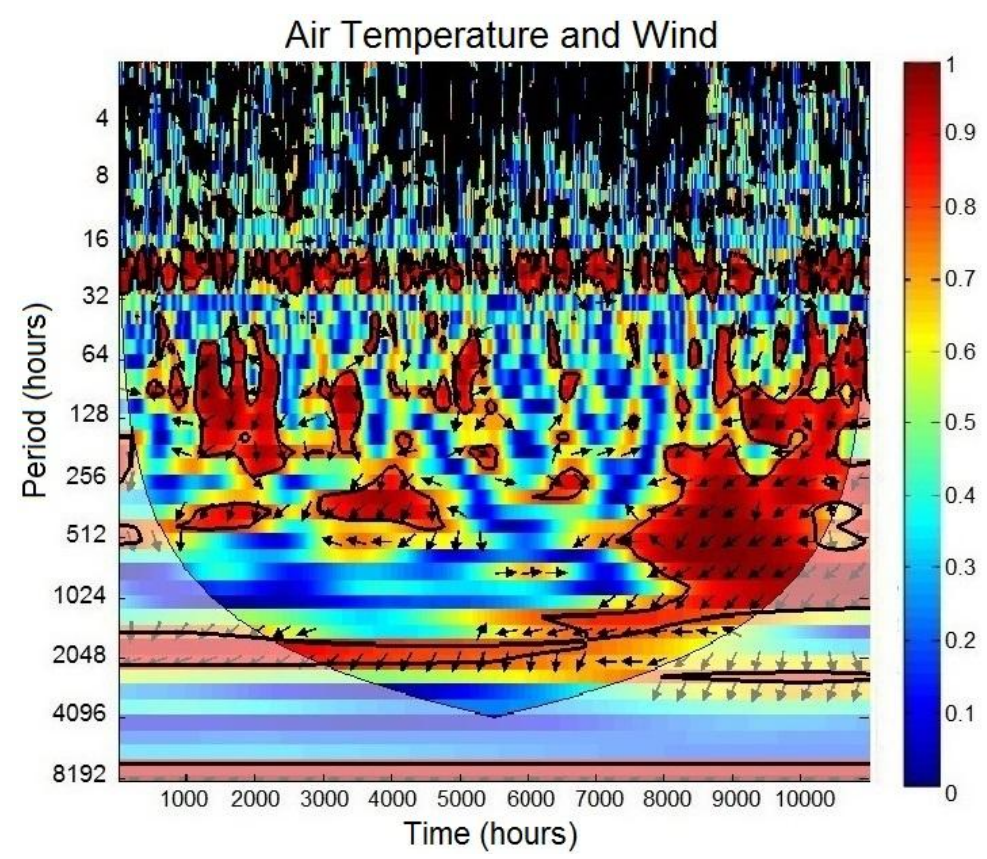

Figure $\mathbf{1 0}$ - WC of temperature and wind

The WC of the temperature and wind (Figure 10) and relative humidity and wind (Figure 11) confirm the $24 \mathrm{~h}$ periodicity. The fortnightly periodicities are also confirmed, and present levels of significance $>95 \%$ following the Monte Carlo tests.

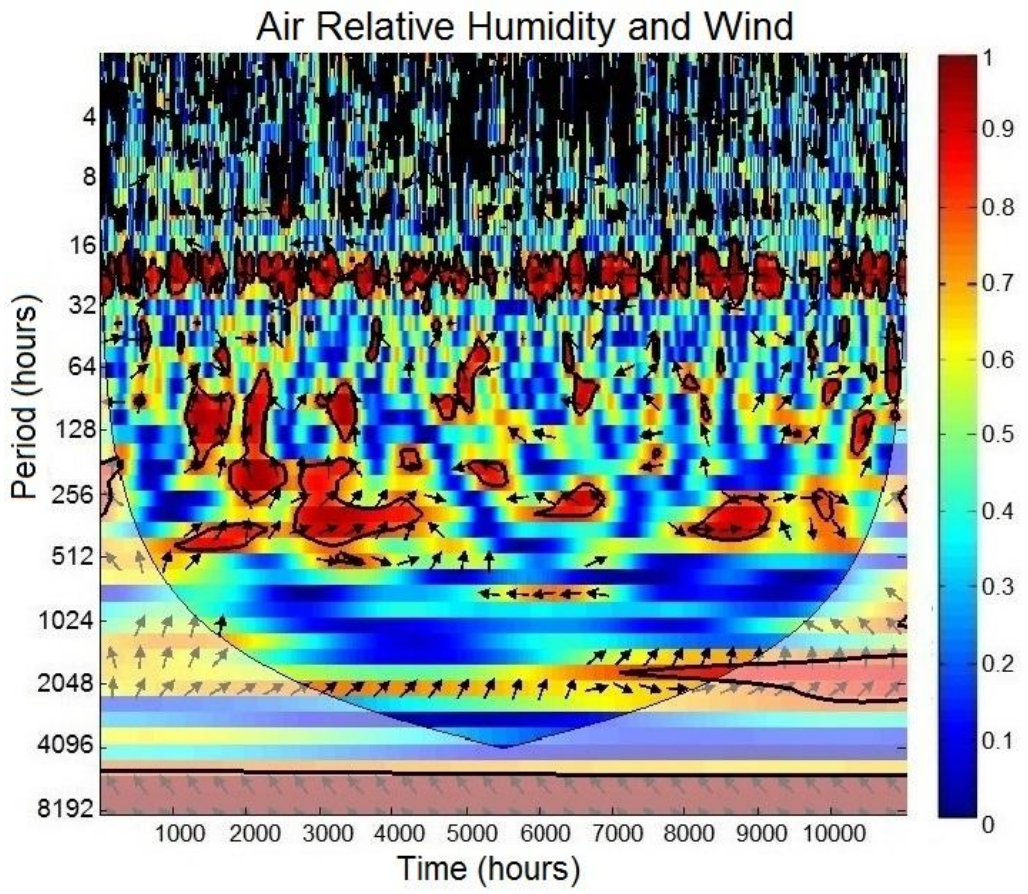

Figure $\mathbf{1 1}$ - WC of relative humidity and wind 
As the tropical regions to which the city of Cuiabá belongs are extremely influenced by seasonality, they can be monitored via XWT plus WC in the different climate scales, as these have proven efficient in quantitative studies for urban analyses in search of a balance between the time and frequency domains. It must be considered that, in order to understand and accept these facts, it is necessary to understand the relative role that vegetation plays in the environment and the verification of water accumulation in the soil and atmosphere, as well as the topography, soil use and occupation, radiation and energy balance, thermal comfort, etc. that is, the climatology in relation to human populations and their urban habitat over time.

\section{CONCLUSIONS}

The time-frequency analysis technique employed in this study favors the qualitative evaluation of an urban system, as using values without an in-depth analysis of their meaning involves the risk of a false interpretation of results, which changes the energy profile and part of the real dynamics of an urban system.

With the Continuous Wavelet Transfer (CWT), the Morlet analytic signal was used through the mapping of the time-frequency domain, which read the spectral content of each temperature, relative humidity, and wind signal by means of the temporal multi-resolution process in the time-frequency domain resolution for each of the time series studied. The variables were thus characterized according to their locations in the time-frequency space.

Interrelations between the variables and the coefficients representing them were found by means of the Cross Wavelet Transfer (XWT), and the patterns indicating the power of the XWT series were obtained. The statistical coherence of the model was evaluated by means of the Wavelet Coherence (WC) on the patterns of energy density obtained by the XWT, which were verified by the Monte Carlo tests.

Therefore, the objectives of this paper were reached with the frequency monitoring analyses through the study of the micrometeorological variables temperature, relative humidity, and wind. The interrelations found in this study suggest the effects of the environments on the variables, as well as those of anthropogenic action on the environment. Considering the depth of these analyses, the CWT, XWT and WC proved to be a robust analysis for urban management. The technical performance of this monitoring depends on a good estimate of the statistics of the digital signal assessed, which in turn represents greater care in the management and implementation of structural change indicators derived from frequency-domain modeling.

These techniques can be further associated with those in the time domain that are aimed at structural analysis for forecasting purposes. Therefore, the techniques in the time domain are complementary analyses that also characterize urban areas. Therefore, improving thermal comfort before and after an urban enterprise, energy consumption prognostics, and sustainability in general are examples of application of the XWT and WC tools proposed in this study. 


\section{ACKNOWLEDGEMENTS}

The authors are grateful to Instituto Federal de Educação, Ciência e Tecnologia de Mato Grosso, Campus Octayde Jorge da Silva, for the financial support. We would also like to thank Universidade Federal de Mato Grosso and the Graduate Studies Program in Environmental Physics.

\section{BIBLIOGRAPHIC REFERENCES}

ADDISON, P. S. The Illustrated Wavalet Transform Handbook. 2 ed. CRC Press Tylor \& Francis Group, 2017. 446p.

ARAGHI, A., et al. Using wavelet transforms to estimate surface temperature trends and dominant periodicities in Iran based on gridded reanalysis data. Atmospheric Research. 2015. v.155; p52-72.

ALVARES, et al. Koppen's climate classification map for Brazil. Meteorologische Zeitschrift, Vol. 22, No. 6, 711-728, January, 2013.

BARROS, M. P. Identifying The Popular References Of Rainfall Prediction In Observed Precipitation Trends In The Brazilian Savanna. International Journal of Recent Scientific Research. Vol. 9, Issue, 4(M), pp. 26425-26431, april, 2018.

COX, E. P. Interação entre clima e superfície urbanizada: o caso da cidade de Várzea Grande/MT. 2008. 141f. Dissertação em Física Ambiental, Programa de Pós-Graduação em Física Ambiental, UFMT, Cuiabá, 2008.

CUIABÁ. Prefeitura Municipal de Cuiabá. Disponível em <http://www.cuiaba.mt.gov.br>: Acesso em: 16 jul. 2017.

DOMINGUES, M.O. et al. Explorando a transformada wavelet contínua. Revista. Brasileira de Ensino de Física. n.3, vol.38, e3314, 2016.

EHLERS, R. S. Análise de Séries Temporais. Curso de Séries Temporais. 2009.

FENG Y., LIANG C. Developing a termal atlas for climate-responsive urban design based on empirical modeling and urban morphological analysis. Energy and Buildings. Shanghai, China.v.111, p. 120-130, jan. 2016.

PROJETO BIOMAS. Disponível em: < http://www.mma.gov.br/ biomas >. Acesso em: 16 jul. 2017.

FRICK, P., GROSSMANN, A. and Tchamitchian, P. Wavelet analysis of signals with gaps. Journal of Mathematical Physics, v.39, 4091-4107, 1998.

http://paos.colorado.edu/research/wavelets, acessado em: October 27. 2016.

http://noc.ac.uk/using-science/crosswavelet-wavelet-coherence, acessado em: October 27. 2016.

LABAKI, L. C. et al. Vegetação E Conforto Térmico Em Espaços Urbanos Abertos. Fórum Patrimônio. v. 4, n. 1, 2013.

NOGUEIRA, M.C.J.A.; FRANCO, F M.; MUSIS, C R.; DURANTE, L.C.; Atributos bioclimáticos urbanos uma análise sobre 0 ponto de vista qualitativo. REMOA/UFSM. v.10, n.10, 2012.

OKE, T. R. Initial guidance to obtain representative meteorological observations at urban sites. IOM Report, TD. World Meteorological Organization, Geneva, 2006. 
REBOITA, et al. Regimes de precipitação na américa do sul: uma revisão bibliográfica. Revista Brasileira de Meteorologia, v.25, n.2, 185-204, 2010.

ROCHA, A. F.; SILVA, E. P.; MUSSIS, C. R.; Topoclimate in Morlet, Cross and Coherence Wavelet Analysis in Brazilian Cerrado. Floram-Floresta Ambient. vol.25 no.4 Seropédica, Epub Sep 13, 2018.

ROMERO, M. A. B. Princípios Bioclimáticos Para o Desenho Urbano. São Paulo: Projeto, 2a edição, 2000. 128 p.

SAMPAIO, M. M. A. The Law of Use and Land Occupancy Cuiaba-MT and Its Environmental Consequences. Engineering and Science / Cientific Journal of Faet and ICET UFMT. 2015.

SETTE, D. M. (2000). O holorritmo e as interações trópico extratrópico na gênese do clima e as paisagens do Mato Grosso. Tese de doutorado Departamento de Geografia USP.

STRANG, G. Wavelet transform versus Fourier transforms. USA, Bulletin of the American Mathematical Society, v. 26, n.2, p. 288-304, 1993.

SHINZATO, P.; DUARTE, C. H. S. Impacto da vegetação nos microclimas urbanos e nos espaços abertos em função das interações solo-vegetaçãoatmosfera. Ambiente Construído, Porto Alegre, v. 18, n. 2, p. 197-215, abr./jun. 2018.

TORRENCE C.; COMPO, Y.G.P. A practical guide to Wavelet analysis. Bulletins of American Meteorological Society, v.79, p.61-78, 1998.

TORRENCE, C.; WEBSTER, P. J. Interdecadal Changes in the Enso-monsoon System. Journal of Climate, v. 12, nº 08, p. 2679-2690, 1999.

$V A L, J$, et al. Addressing the local aspects of global change impacts on stream metabolism using frequency analysis tools. Science of the Total Environment, 2016, v.569-570; p.798-814.

VILANI, M.T.; REIS, M. N. S.; PINTO JUNIOR, O. B.; NOVAIS, J. W. V. Coerência Wavelets em Variável Temperatura do Ar em Área do Bioma Pantaneiro e Área de Alta Densidade Construtiva. Ensaios Cienc., v. 22, n. 1, p. 5-11, 2018. 